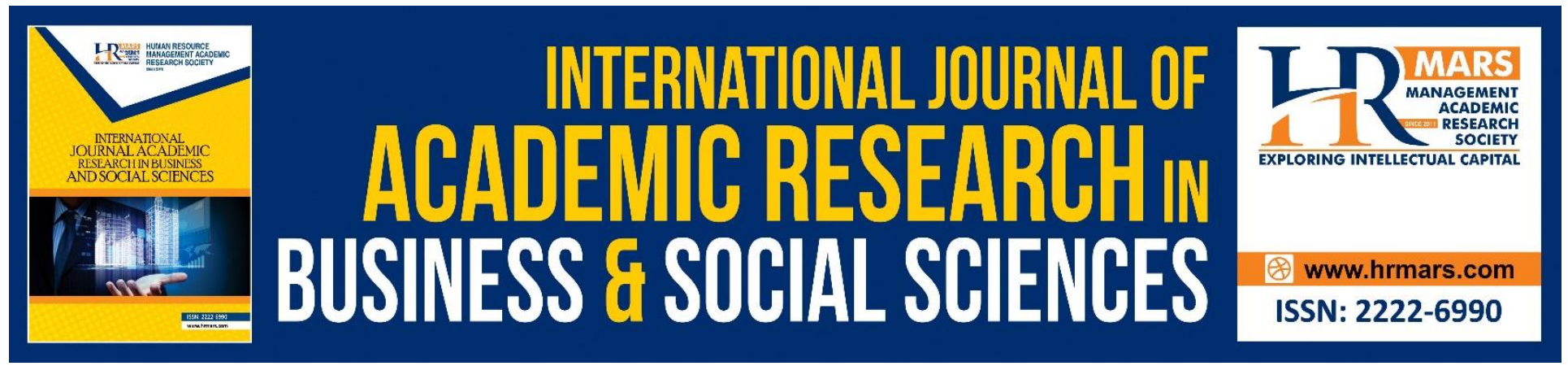

\title{
Zakat Distribution to Fi Sabilillah Asnafin Higher Education Institutions: Universiti Teknologi Malaysia Experience
}

Nasrul Hisyam Nor Muhamad, Mohd Fami Mohd Sahid, Mohd Khairy Kamarudin, Kamaliah Abdul Karim

To Link this Article: http://dx.doi.org/10.6007/IJARBSS/v8-i9/4580

DOI: $\quad 10.6007 /$ IJARBSS/v8-i9/4580

Received: 11 July 2018, Revised: 19 August 2018, Accepted: 29 August 2018

Published Online: 18 September 2018

In-Text Citation: (Muhamad, Sahid, Kamaruddin, \& Karim, 2018)

To Cite this Article: Muhamad, N. H. N., Sahid, M. F. M., Kamaruddin, M. K., \& Karim, K. A. (2018). Zakat

Distribution to Fi Sabilillah Asnaf in Higher Education Institutions: Universiti Teknologi Malaysia Experience. International Journal of Academic Research in Business and Social Sciences, 8(9), 138-149.

Copyright: (C) 2018 The Author(s)

Published by Human Resource Management Academic Research Society (www.hrmars.com)

This article is published under the Creative Commons Attribution (CC BY 4.0) license. Anyone may reproduce, distribute, translate and create derivative works of this article (for both commercial and non-commercial purposes), subject to full attribution to the original publication and authors. The full terms of this license may be seen

at: http://creativecommons.org/licences/by/4.0/legalcode

Vol. 8, No. 9, September 2018, Pg. 138 - 149

http://hrmars.com/index.php/pages/detail/IJARBSS

JOURNAL HOMEPAGE

Full Terms \& Conditions of access and use can be found at http://hrmars.com/index.php/pages/detail/publication-ethics 


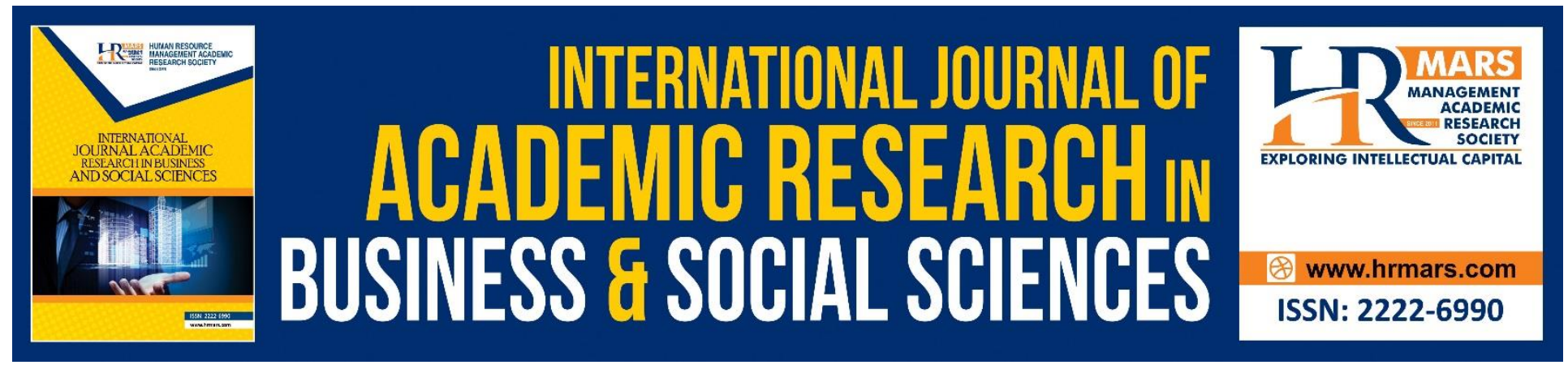

\title{
Zakat Distribution to Fi Sabilillah Asnafin Higher Education Institutions: Universiti Teknologi Malaysia Experience
}

\author{
Nasrul Hisyam Nor Muhamad \\ Senior Lecturer, Faculty of Islamic Civilization, Universiti Teknologi Malaysia \\ Email: nasrul@utm.my
}

Mohd Fami Mohd Sahid

Faculty of Education, Universiti Teknologi Malaysia

Mohd Khairy Kamarudin

Postgraduate Student, Faculty of Islamic Civilization, Universiti Teknologi Malaysia Lecturer, Faculty of Entrepreneurship and Business, Universiti Malaysia Kelantan

Email: khairy.k@umk.edu.my

Kamaliah Abdul Karim

Postgraduate Student, Faculty of Islamic Civilization, Universiti Teknologi Malaysia Email: kamaliah57abdkarim@gmail.com

\begin{abstract}
Most of the higher education institutions in Malaysia have a specific unit or department which handle the collection and distribution of zakat in their institutions. This study aims to examine asnafs' perception on the process and effectiveness of the zakat distribution to fi sabilillah asnaf which has been implemented by the Zakat Unit, Islamic Centre, Universiti Teknologi Malaysia (UTM). The samples in this study are UTM students who have received zakat from the Zakat Unit. A set of questionnaire is distributed to the respondents and analyzed descriptively by using IBM SPSS version 22. The reliability value of this questionnaire is $\alpha=0.845$. This study indicates the zakat distribution to fi sabilillah asnaf that is implemented by the Zakat Unit, UTM is well positioned. Respondents also agree that the Zakat Unit of UTM as a zakat management centre eases the burden among students in pursuing their studies.
\end{abstract}

Keyword(s): Zakat distribution, Zakat Unit, Fi Sabilillah, Asnaf, Asnafs' Perception

Introduction 
INTERNATIONAL JOURNAL OF ACADEMIC RESEARCH IN BUSINESS AND SOCIAL SCIENCES

Vol. 8, No. 9, Sept. 2018, E-ISSN: 2222-6990 @ 2018 HRMARS

Each state in Malaysia has its own department to manage zakat matters. Generally, all management aspects such as collection and distribution of zakat is managed by the Islamic Religious Council (Majlis Agama Islam) in each respective state. However, to facilitate the zakat management, some states have set up their own zakat institutions as a corporate or private entity (A. H. Mohd Noor et al. 2015). For example, in the State of Johor, zakat management is handled by Majlis Agama Islam Johor (MAINJ) (Johor Islamic Religious Council), under Zakat and Fitrah Committee (Aminuddin et al. 2017).

Even though this council is responsible to manage zakat, there are shortcomings that require to be improved from the collection and distribution aspects (Ibrahim 2015). This can be seen on the prevailing scenario in the society particularly in the public and private sectors of the higher education. There are still many candidates who are eligible to pursue their studies at higher education institutions, but they have lack of financial support (BERNAMA 2017; Hamid 2017). Zakat institutions should give priority to education in order to increase the number of human capitals as well as to attain and sustain economic development (Yusoff 2011, 2014).

Expenditure cost in university is associated with current cost of living (Abdul Razak et al. 2017; Idris et al. 2013) and education (Hassan and Rasiah 2011; Migin et al. 2015). The difficult life at university contributes to high level of stress among students. As a result, it affects their performance in examinations (Turner et al. 2015). Due to financial problems, some of them decide to work as parttimers to cover their cost of living (Ahmad 2016). Therefore, this study applauds when some zakat institutions consider students in university as one of the eight asnaf ${ }^{1}$, part of fi sabilillah asnaf ${ }^{2}$.

Currently, some zakat institutions implement localization concept of zakat management with several universities. Zakat institutions empower zakat collection and distribution to the universities where they will act as amil ${ }^{3}$. For example, Lembaga Zakat Selangor has collaborated with Universiti Teknologi Mara (UiTM), Kolej Antarabangsa Universiti Islam Selangor (KUIS), Universiti Tenaga Nasional (UNITEN), Universiti Multimedia Malaysia (MMU), Universiti Tun Abdul Razak (UNITAR) and Universiti Selangor (UNISEL) (Jalil et al. 2017). Jalil et al. (2017) indicate level of perception and confidence among students towards Zakat Unit in higher education institution is still low particularly on amil roles. However, the research limit to the concept of localization of zakat distribution among asnaf in higher education institution. The nature of students' perception as zakat recipients towards the effectiveness of zakat management at higher education institution remain unclear. Therefore, the aim of this investigation to fill his gap.

\section{Literature Review}

The word of 'zakat' can be defined with various definition such as purity, blessing, growing, thriving and neatness (Al-Qaradawi 2002; Md Razak et al. 2013; Tarimin 2012). Meanwhile, in terms of concept, zakat is referred to the payment of compulsory levy which compulsory to Muslims who meet certain conditions and requirements. This compulsory levy is a wealth distribution mechanism in a community from the rich to the poor, with the ultimate goal to reduce the gap (Wahid et al. 2012).

\footnotetext{
${ }^{1}$ Eligible zakat recipient

2 In the cause of Allah

${ }^{3}$ Zakat collector
} 
INTERNATIONAL JOURNAL OF ACADEMIC RESEARCH IN BUSINESS AND SOCIAL SCIENCES

Vol. 8, No. 9, Sept. 2018, E-ISSN: 2222-6990 @ 2018 HRMARS

Consequently, zakat institution is one of the preferred institution to eliminate poverty and maintain socioeconomic justice (Othman and Abdul Ghani 2011). The efficiency of zakat collection and distribution depend on good governance which is practiced by zakat institution. At the same time, a significant aspect in zakat management is zakat distribution which the objective of zakat is to reduce poverty and enhance quality of asnafs' life (Abd Wahab and Abdul Rahman 2012).

Research on zakat covers various topics including concepts and law (Tarimin 2012), regulation and enforcement (Hussin et al. 2013; Md Idris 2002), accounting (Abdul Rahman, 2003) and zakat payer behaviours (Kamil and Ahmad Mahdzan 2002; Mohd Noor et al. 2004; Saad 2010). Currently most of the literature focus on zakat institution management such as Abd Wahab and Abdul Rahman (2012), Ahmad Razimi et al. (2016), Azman et al. (2012), Ishak and Maamor (2013), Saad (2010), Wahid et al. (2010) and Zainal et al. (2016).

In terms of zakat institution management, Ag Omar et al. (2017) and Aminuddin et al. (2017), discover that financial management performance by zakat institution shows capability to meet current liability obligations and consistency of profit ratio for most year. In addition, zakat institution shows a high commitment and cooperation to achieve MS1900 (Malaysian Islamic Quality Management System). The basic elements of this quality management are compliance to halal (legal) and haram (illegal) activities, and operate based on values and decision in line with Maqasid Shariah (Shariah Objective) (Basir et al. 2017).

Zainal et al. (2016) has established a conceptual model that proposes trust in zakat institution is influenced by reputation, satisfaction of zakat distribution and service quality. This paper develop conceptual model through literature review methods. In addition, Ahmad Razimi et al. (2016) recommend that in order to enhance the efficiency of zakat management, there are five main points namely number of staff, ICT Usage, Corporate Governance, Number of branches and corporation. Meanwhile, Ishak and Maamor (2013) analyse the efficiency of Federal Territories Kuala Lumpur, Putrajaya and Labuan through DEA. They indicate that zakat management in these three territories are efficient due to many zakat collection counters. As many zakat collection counter, they will increase zakat collection and zakat payers. Hussin et al. (2013) suggest that zakat institution should held briefing section to share the importance of paying zakat to the public. Zakat collection method should be manage systematically to ensure zakat could be paid easily and asnaf will receive the assistance promptly.

\section{Research Methodology}

This study employs quantitative approach in which the data is collected through questionnaire. Samples in this study are Muslim students who receive zakat from Zakat Unit, Islamic Centre, UTM. The set of questionnaire is divided into four sections; $A, B, C$ and $D$ and the total number of questions are 37 items. Section A consists 7 items regarding respondents' personal information; gender, age, marital status, education background, years of studies, parent's or guardian's income and types of zakat that the respondents have received. For section $B, C$ and $D$, the items are the information on the perception of asnaf on zakat distribution management to fi sabilillah asnaf that has been carried out by Zakat Unit, UTM. In Section B, there are 10 focus items on the perception of asnaf towards Zakat Unit, UTM. While, Section C is about asnafs' perception towards the implemented distribution process to fi sabilillah asnaf. The respondents are asked 10 questions for this section. Lastly, Section 
INTERNATIONAL JOURNAL OF ACADEMIC RESEARCH IN BUSINESS AND SOCIAL SCIENCES Vol. 8, No. 9, Sept. 2018, E-ISSN: 2222-6990 @ 2018 HRMARS

D is to measure asnafs' perception towards how zakat is utilized by the zakat recipients among UTM students. For this purpose, 10 items have been questioned.

Participants are asked to show their level of agreement (from strongly disagree to strongly agree) with the given statement (items) on a metric scale (Joshi, Kale, Chandel, \& Pal, 2015). The levels of this scale are as follow:

$1=$ Strongly Disagree

$2=$ Disagree

$3=$ Neutral

$4=$ Agree

5 = Strongly Agree

\section{Finding and Discussion}

Universiti Teknologi Malaysia (UTM) which is located in Johor also collaborates with MAINJ. MAINJ has signed Memorandum of Agreement (MOA) for zakat management and distribution with UTM on 24 May 2006. With the MOA, it gives students opportunities to pursue their studies in the university. As a result, a small Zakat Unit was set up under the UTM Islamic Centre in collaboration with MAINJ. This unit operates to collect zakat from staff and distribute it to fi sabilillah asnaf only (Pusat Islam UTM n.d.).

Total respondents in this study are 60 students who receive zakat from the Zakat Unit, Islamic Centre UTM. 41 respondents (68.3\%) are males and 19 respondents (31.7\%) are females. In addition, most of the respondents (90\%) are between 22 to 25 years old and the remaining (10\%) are between 18 to 21 years old. This study finds that majority of the respondents are singles (95\%) and only 5\% are married. In terms of the highest education background before enrolment at UTM, 38.3\% are from Matriculation, followed by from National High School (31.7\%), 16.7\% students graduated from other Public or Private Higher Education Institute, Polytechnic and Mara Junior Science College and lastly from National Religious Secondary Schools and People's Religious School (13.3\%). Based on years of studies, $38.3 \%$ are students who extend their semester of studies or postgraduate students. For this category, normally they do not receive any scholarship, thus it become one of the factors why they apply for zakat. Next is the final year students (20\%) who need zakat to ease the burden of cost and expenditure to prepare their Final Year Project (FYP) especially for engineering students. Meanwhile, the findings show that those who are applying zakat the most come from modest families. Their parents or guardians' income is in the range between RM200 to RM700 monthly (66.7\%). Then followed by RM701 to RM1200 (20\%) and RM1201 and above (13.3\%). On the other side, most of them received free refreshment coupons (73.3\%), followed by tuition fees (18.3\%) and cost of living allowance (8.3\%)

This study indicates asnafs' perception towards the Zakat Unit, Islamic Centre, UTM as follows in Table 1. Overall, based on this result, this study concludes that respondents strongly agree for Zakat Unit to be zakat management centre (Mean $=4.61$ ). The highest mean is Zakat1 where respondents strongly agree that Zakat Unit, UTM as the zakat management centre should continue assisting student financial problems (Mean $=4.90$ ). In addition, they also agree that Unit Zakat facilitates their application for zakat (Mean $=4.88$ ). Furthermore, the third highest is Zakat3, in which they agree Zakat Unit can solve the financial problems among Muslims especially students. This matter is 
INTERNATIONAL JOURNAL OF ACADEMIC RESEARCH IN BUSINESS AND SOCIAL SCIENCES Vol. 8, No. 9, Sept. 2018, E-ISSN: 2222-6990 @ 2018 HRMARS

supported by many zakat and economics scholars such as Ali and Hatta (2014), Anis and Kassim (2016), Azam et al. (2014), Irijanto et al. (2017) and Malik (2016). Zakat4 and Zakat5 indicates that most of the respondents strongly agree that Zakat Unit runs the zakat distribution fairly and in accordance to the requirements of Islam (Mean $=4.72$ ) and their staff deliver good and customer friendly services (Mean $=4.65$ ). All funds obtained from the collection of zakat must be distributed equally and fairly according to the priority. Abdul Lateff et al. (2014) and Ag Omar et al. (2017) agree that fair zakat distribution by zakat institutions is associated with the collection, distribution performance and their efficiency. Staff who are willing to provide good and customer friendly services will promote higher service quality and satisfaction to the zakat payers (Wahab et al.. At the same time, in order to ensure the commitment and motivation of staff, Amran and Md Auzair (2013) recommend that they should receive compensation incentives to maintain their performance. Respondents also strongly agree zakat management is implemented professionally and systematically (Mean $=4.6$ ). It is followed by Zakat9 in which respondents strongly agree that Zakat Unit emphasized transparency in zakat collection and distribution matters (Mean =4.5). Adnan (2017) agrees that professionalism in zakat management is observed by Zakat Institutions. The profesional zakat management will foster zakat movement. As a result, zakat institutions in Malaysia has been incorporated in 1991 (Basir et al. 2017). Systematically zakat distribution is also proven able to liberate Muslims from poverty (Abd Rahman et al. 2015). In terms of transparency, Taha et al. (2017) argue that zakat management in Malaysia has lack of transparency because insufficient information is disclosed by the zakat institutions. However, some of the information has high level of confidentiality and is considered private in nature by zakat institutions.

Table 1: Mean distribution of asnafs' perception towards Zakat Unit, Islamic Centre, UTM

\begin{tabular}{|l|l|l|l|}
\hline Label(s) & Item(s) & Mean & Perception \\
\hline Zakat1 & $\begin{array}{l}\text { Islamic Centre, UTM as the zakat management center should continue assisting student } \\
\text { financial problems. }\end{array}$ & 4.90 & Strongly agree \\
\hline Zakat2 & The establishment of the Zakat Unit facilitates the application of zakat among students. & 4.88 & Strongly agree \\
\hline Zakat3 & $\begin{array}{l}\text { The establishment of this Zakat Unit can solve the financial problems among Muslims } \\
\text { especially students. }\end{array}$ & 4.78 & Strongly agree \\
\hline Zakat4 & Zakat Unit runs the zakat distribution fairly in accordance to the requirements of Islam. & 4.72 & Strongly agree \\
\hline Zakat5 & Staff at Zakat Unit deliver good and customer-friendly services. & 4.65 & Strongly agree \\
\hline Zakat6 & Zakat management is carried out professionally and systematically. & 4.60 & Strongly agree \\
\hline Zakat7 & Customer satisfaction is given priority by this Zakat Unit. & 4.58 & Strongly agree \\
\hline Zakat8 & $\begin{array}{l}\text { Transparency in zakat collection and distribution matters receives the utmost emphasis } \\
\text { in the Zakat Unit. }\end{array}$ & 4.50 & Strongly agree \\
\hline Zakat9 & The total amount of zakat distribution takes into account all aspects of students' needs. & 4.40 & Strongly agree \\
\hline Zakat10 & Zakat aid is sufficient to meet life necessities in university. & 4.13 & Strongly agree \\
\hline & Overall & $\mathbf{4 . 6 1}$ & \\
\hline
\end{tabular}

While asnafs' perception on the process of zakat distribution implemented by Unit Zakat, Islamic Centre, UTM is shown in Table 2. Zakat11 is the highest item for this section (Mean $=4.63$ ) which indicates that zakat distribution process is systematic and professional. Respondents also strongly 
INTERNATIONAL JOURNAL OF ACADEMIC RESEARCH IN BUSINESS AND SOCIAL SCIENCES Vol. 8, No. 9, Sept. 2018, E-ISSN: 2222-6990 @ 2018 HRMARS

agree that the process of determining students who are eligible to receive zakat is carefully implemented (Mean $=4.55$ ). To apply zakat, applicants must fill form which will be processed and later they will be interviewed by the Zakat Unit officer. Then, results will be discussed in the executive meeting conducted by the Islamic Centre, UTM to determine whether the applicants are eligible to receive zakat. Finally, the result will be announced on the Islamic Centre Office notice board. Additionally, respondent strongly agree that zakat distribution meets the applicant's needs (Mean = 4.48). This is based on types of zakat distribution that has been offered to applicants. There are two types of zakat for fi sabilillah at Zakat Unit. The first type of zakat is general zakat that consists of two forms; student programs and tafaqquh classes. The second type of zakat is individual assistance; refreshment coupon assistance, tuition fees and cost of living allowance. They also agree that the methods of zakat distribution to eligible asnaf is effective (Mean $=4.43$ ). For example, refreshment coupon assistance is seen to be effective because the students only use this coupon to get free meals from selected cafeteria as set by the Zakat Unit. Indirectly, this assistance can help reduce the burden of purchasing meals which is the basic thing of life. More importantly, this study discovers Zakat20 in which the Zakat Unit of UTM as a zakat management body has been known by students through publicity, posters and advertisements has the lowest mean among other items (Mean $=3.73$ ). This is because the publicity on zakat distribution is only done around the Zakat Unit, UTM and not at the faculties or students' residential colleges. Furthermore, current zakat funds cannot accommodate all deserving students although they are eligible to apply. Therefore, it needs to be conserved and allocated carefully according to students' priorities and needs. In summary, respondents strongly agree that Zakat Unit, UTM has implemented zakat distribution process effectively and professionally based on overall mean (Mean $=4.35$ ). Zakat distribution effectiveness can be measured as for improving the lives of poor and needy. It will assist the recipients to become productive and help to ease their financial burden (Ahmed et al. 2017; Djaghballou et al. 2018; Mayes et al. 2017).

Table 2: Mean distribution of asnafs' perception on the process of zakat distribution that implemented by Unit Zakat, Islamic Centre, UTM

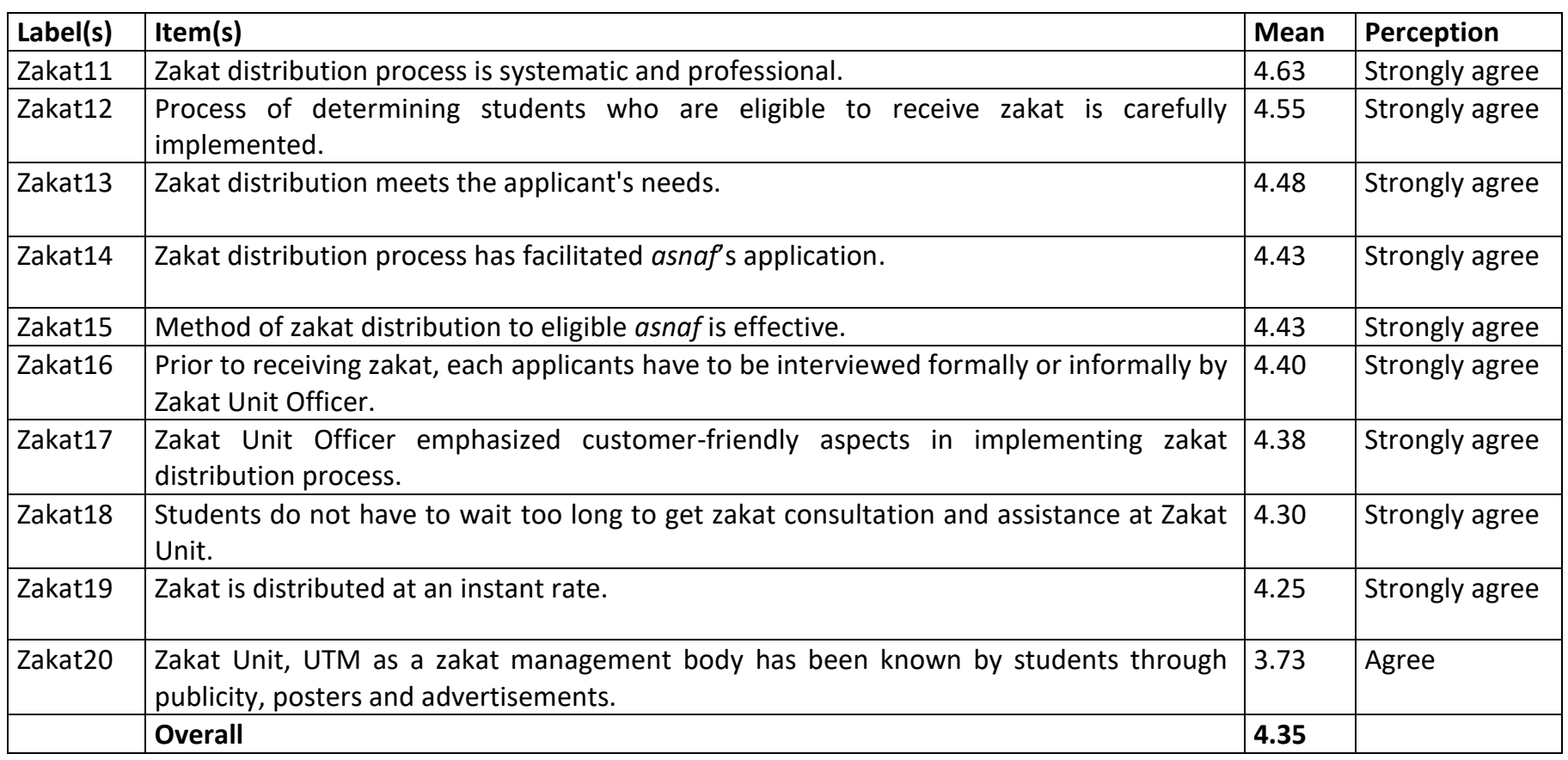


INTERNATIONAL JOURNAL OF ACADEMIC RESEARCH IN BUSINESS AND SOCIAL SCIENCES Vol. 8, No. 9, Sept. 2018, E-ISSN: 2222-6990 @ 2018 HRMARS

Table 3 shows mean distribution of asnafs' perception on the consumption of zakat distribution by Zakat Unit, Islamic Centre, UTM. The findings show how students use zakat aid in a positive way. They strongly agree that zakat aid is used for beneficial matters in their university lives (Mean =4.57). They also strongly agree that zakat aid is a trust (Mean $=4.77$ ). Therefore asnaf will feel guilty when zakat aid is used for other than the educational needs (Mean $=4.72$ ). To survive university life, zakat aid is used prudently and economically (Mean $=4.68$ ), for the purpose of university life (Mean = 4.65) and their studies (Mean $=4.58$ ). They also used zakat aid to pay tuition fees, refreshment, books and learning equipment (Mean $=4.62$ ). This study validates the two types of zakat distribution by the Zakat Unit can ease students' financial burden. Apart from that, zakat aid requires students to do their financial planning wisely in order to meet their necessities (Mean $=4.58$ ). However, Zakat30 shows the lowest mean of asnafs' perception on the consumption of zakat distribution by Zakat Unit, UTM (Mean = 3.8). It demonstrates that some of the respondents prefer to choose other methods to receive zakat fund instead of the direct bank deposit. This study recommends that zakat fund should be distributed to asnaf by cash as it will be easier for them.

\section{Table 3 : Mean distribution of asnafs' perception on the consumption of zakat distribution by} Zakat Unit, Islamic Centre, UTM

\begin{tabular}{|l|l|l|l|}
\hline Label(s) & Item(s) & Mean & Perception \\
\hline Zakat21 & Zakat aid is a trust. & 4.77 & Strongly agree \\
\hline Zakat22 & Zakat aid can ease family burden & 4.72 & Strongly agree \\
\hline Zakat23 & $\begin{array}{l}\text { Guilty feeling will dominate when zakat aid is used for other than the needs for } \\
\text { studies }\end{array}$ & 4.72 & Strongly agree \\
\hline Zakat24 & Zakat aid is used prudently and economically. & 4.68 & Strongly agree \\
\hline Zakat25 & Zakat aid is used for the purpose of campus life. & 4.65 & Strongly agree \\
\hline Zakat26 & Zakat aid is used to pay fees, refreshment, buy books and learning equipment. & 4.62 & Strongly agree \\
\hline Zakat27 & Zakat aid is used entirely for the purpose of studies. & 4.62 & Strongly agree \\
\hline Zakat28 & Zakat aid is divided its consumption to meet the needs in campus. & 4.58 & Strongly agree \\
\hline Zakat29 & $\begin{array}{l}\text { Zakat aid can help asnaf to make financial planning in managing the necessities } \\
\text { of life. }\end{array}$ & 4.58 & Strongly agree \\
\hline Zakat30 & Zakat aid is deposited in the bank and withdrawn when needed. & 3.80 & Agree \\
\hline & Overall & $\mathbf{4 . 5 7}$ & \\
\hline
\end{tabular}

This study recommends that MAINJ should continue to mandate and maintain the Zakat Unit of UTM as one of the zakat management institutions in assisting fi sabilillah asnaf, especially UTM's students. To this extent, Zakat Unit, UTM is only a small unit within MAINJ with two years contract to manage zakat collection and distribution to fi sabilillah asnaf. Therefore, the Zakat Unit, UTM should expand their function in order to increase zakat collection and distribution. Furthermore, as the current Zakat Officers are temporary and contract-based, permanent post should be created in order to manage zakat collection and distribution professionally and systematically so that a lot of workloads can be completed by several staff instead of only one or two staff. In addition, there must be collaboration between the Treasurer Unit, UTM and the Zakat Unit, UTM to facilitate payment for outstanding tuition fees of the students. Collaboration between UTM administration to raise awareness among UTM staff regarding the obligation for Zakat on salary and income also should be emphasized. Zakat on income will address the problem of inadequate zakat fund at the Zakat Unit 
INTERNATIONAL JOURNAL OF ACADEMIC RESEARCH IN BUSINESS AND SOCIAL SCIENCES

Vol. 8, No. 9, Sept. 2018, E-ISSN: 2222-6990 @ 2018 HRMARS

which needs to be distributed to the needy student ( $\mathrm{fi}$ sabilillah asnaf). Furthermore, the publicity about this Zakat Unit should be expanded as zakat management centre and zakat aid schemes which are offered by Zakat Unit. The publicity should not focus only around the Zakat Unit, but cover all student residential colleges, administrative offices and faculties. This is because many staff still have lack of information about their obligations to pay zakat on income, and at the same token, some students also do not know their rights for the zakat distribution.

\section{Conclusion}

This work is to investigate students' perception as zakat recipients towards the effectiveness of zakat management at higher education institution. This is performed by descriptive analysis which the data is obtained through questionnaires. This study discover that Zakat Unit in higher education institution is recognized as zakat management centre. Therefore, this Zakat Unit should play important roles to assist students who encounter financial burden. In addition, this study indicates that Zakat Unit has applied zakat distribution process effectively and professionally. It means that zakat aid to the students is adequately and meets the students' needs. Lastly, this study realise that students use zakat aid in a positive ways such as for beneficial matters, to survive in university life and studies, to pay tuition fees, to purchase refreshment, books and learning equipment. This study recommend that Zakat Unit, should be continued as zakat collection and distribution centre to assist students who face financial burden. At the same time, Zakat Unit should expand their function and increase permanent post to ensure zakat will be managed professionally and systematically.

\section{References}

Abd Wahab, N., \& Abdul Rahman, A. R. (2012). Efficiency of zakat institution in Malaysia: An application of Data Envelopment Analysis. Journal of Economic Cooperation and Development, 1(205), 95-112.

Abdul Lateff, E. E., Palil, M. R., \& Hassan, M. S. (2014). Financial and non-financial distribution efficeincy performance among zakat institutions in Malaysia. Jurnal Ekonomi Malaysia, 48(2), 51-60.

Abdul Rahman, A. R. (2003). Zakat on business wealth in Malaysia: Corporate Tax Rebate, Accountability, and Governance. Jurnal IKIM, 11(1), 37-50.

Abdul Razak, F., Shariffuddin, N., Mohd Padil, H., \& Hanafi, N. H. (2017). Phenomenon living in offcampus accommodation among UiTM students. International Journal of Academic Research in Business and Social Sciences, 7(6), 786-796. http://doi.org/10.6007/IJARBSS/v7-i6/3038

Adnan, M. A. (2017). The need of establishment of professional amil zakat to enhance the future zakat development. International Journal of Zakat, 2(1), 71-79.

Ag Omar, P. M. F. F., Wahid, H., \& Mohd Nor, M. A. (2017). Efficiency of financial and zakat distribution management: A study at Sabah Islamic Religious Council. Jurnal Syariah, 25(3), 415-452.

Ahmad, M. (2016, December 1). Students work part time for the cost of living. BH Online. Retrieved from https://www.bharian.com.my/node/218705

Ahmad Razimi, M. S., Romle, A. R., \& Muhamad Erdris, M. F. (2016). Zakat management in Malaysia: A review. American-Eurasian Journal of Scientific Research, 11(6), 453-457. http://doi.org/10.5829/idosi.aejsr.2016.453.457

Ahmed, B. O., Johari, F., \& Abdul Wahab, K. (2017). Identifying the poor and the needy among the beneficiaries of zakat: A need fot zakat-based poverty threshold in Nigeria. International 
INTERNATIONAL JOURNAL OF ACADEMIC RESEARCH IN BUSINESS AND SOCIAL SCIENCES

Vol. 8, No. 9, Sept. 2018, E-ISSN: 2222-6990 @ 2018 HRMARS

Journal of Social Economics, 44(4), 446-458.

Al-Qaradawi, Y. (2002). Fiqh al-Zakat. Beirut: Mu'assasat Al-Risalah.

Ali, I., \& Hatta, Z. A. (2014). Zakat as a poverty reduction mechanism among the muslim community: Case study of Bangladesh, Malaysia, and Indonesia. Asian Social Work and Policy Review, 8(1), 59-70. http://doi.org/10.1111/aswp.12025

Aminuddin, A. F., Wahid, H., \& Mohd Nor, M. A. (2017). Efficiency of financial and zakat distribution management: A study at Johor Islamic Religious Council. International Journal of Islamic and Civilization Studies, 4(3), 52-66.

Amran, N., \& Auzair, M. S. (2013). Incentive Compensation, Organizational Commitment and Managerial Performance in Zakat Institutions. Terengganu International Finance and Economics Journal, 3(2), 50-58.

Anis, F. M., \& Kassim, S. H. (2016). Effectiveness of zakat-based programs on poverty alleviation and economic empowerment of poor women: A case study of Bangladesh. Journal of Islamic Monetary Economics and Finance, 1(2), 229-258. Retrieved from http://journalbankindonesia.org/index.php/JIMF/article/view/539

Azam, M., lqbal, N., \& Tayyab, M. (2014). Zakat and economic development: Micro and macro level evidence from Pakistan. Bulletin of Business and Economics, 3(2), 85-95.

Azman, A. R., Mohammad, A., \& Syed Mohd Najib, S. O. (2012). Zakat institution in Malaysia: Problems and issues. Gjat, 2(1), 35-41.

Azman Abd Rahman, Irwan, Nuradli Ridzwan Shah, Mahazan, Wan Mohd Fazrul Azdi, Rose Irnawaty, Ibrahim, N. I. (2015). Skim bantuan zakat asnaf mualaf: Satu analisis kontemporari di Malaysia. Jurnal Infad, 6, 167-191.

Basir, S. A., Azmi Abdul Ghani, I., Syed Ismail, S. H., Ibrahim, P., \& Mohamed, H. A. (2017). Malaysian Islamic Quality Management System MS1900 : An implementation steps at Malacca Zakat Center. HumanomicsEconomics, 33(2), 239-254. http://doi.org/10.1108/H-10-2016-0078

BERNAMA. (2017, March 26). 3,000 places for outstanding students failed to continue their studies at UiTM. Utusan Online. Retrieved from http://www.utusan.com.my/mobile/berita/nasional/3-000-tempat-untuk-pelajar-cemerlanggagal-lanjut-pelajaran-di-uitm-1.462068

Djaghballou, C.-E., Djaghballou, M., Larbani, M., \& Mohamad, A. (2018). Efficiency and productivity performance of zakat funds in Algeria. International Journal of Islamic and Middle Eastern Finance and Management, IMEFM-07-2017-0185. http://doi.org/10.1108/IMEFM-07-20170185

Hamid, N. H. (2017, August 12). KPTM offer 3,000 places for dropout stundets. Sinar Harian. Retrieved from http://www.sinarharian.com.my/mobile/nasional/kptm-tawar-3-000-tempatuntuk-pelajar-tercicir-1.717794

Hassan, O. R., \& Rasiah, R. (2011). Poverty and student performance in Malaysia. International Journal of Institutions and Economies, 3(1), 61-76.

Hussin, M. Y. M., Muhammad, F., \& Ahmad, M. A. R. (2013). Kepatuhan membayar zakat : Analisis kutipan dan ketirisan zakat fitrah di Selangor. Jurnal Syariah, 21(2), 191-206.

Ibrahim, M. S. (2015). Comparative studies on contemporary zakat distribution: A practical experience of some selected Muslims states. Journal for Studies in Management and Planning, 1(7), 286-300. Retrieved from http://edupediapublications.org/journals/index.php/JSMaP/article/view/2580

Idris, F., Devi Krishnan, K. S., \& Azmi, N. (2013). Relationship between financial literacy and financial 
INTERNATIONAL JOURNAL OF ACADEMIC RESEARCH IN BUSINESS AND SOCIAL SCIENCES

Vol. 8, No. 9, Sept. 2018, E-ISSN: 2222-6990 @ 2018 HRMARS

distress among youths in Malaysia - An empirical study. Malaysian Journal of Society and Space, 4(4), 106-117.

Irijanto, T. T., Shah, M. A., \& Ismail, A. G. (2017). The Thoughts of Economic Growth Theories of Classical Muslim Scholars, A Contribution. Economic Journal TRIKONOMIKA, 12(2), 168-189. Retrieved from http://journal.unpas.ac.id/index.php/trikonomika/article/view/478

Ishak, N. H., \& Maamor, S. (2013). Kajian kecekapan kutipan zakat di Wilayah Persekutuan. In Prosiding PERKEM VIII (Vol. 1, pp. 414-425).

Jalil, M. R., Wahid, H., \& Ahmad, S. (2017). Lokalisasi unit zakat institusi pengajian tinggi sebagai model One Stop Center agihan zakat pendidikan. Journal of Fatwa Management and Research, 10, 1-14.

Joshi, A., Kale, S., Chandel, S., \& Pal, D. K. (2015). Likert Scale: Explored and explained. British Journal of Applied Science \& Technology, 7(4), 396-403. http://doi.org/10.9734/BJAST/2015/14975

Kamil, M. I., \& Ahmad Mahdzan, A. (2002). Peranan sikap dalam gelagat kepatuhan pendapatan gaji. Analisis, 9(1 \& 2), 171-191.

Malik, B. A. (2016). Philantrophy in practice: Role of zakat in the realization of justice and economic growth. International Journal of Zakat, 1(1), 64-77.

Mayes, A., Setiawan, D., Isbah, U., \& Zuryani, H. (2017). The role of productive zakat for helping poor community in Rokan Hulu Regency (Case study of National Amil Zakat of Rokan Hulu Regency). International Journal of Finance and Accounting, 6(6), 179-185. http://doi.org/10.5923/j.ijfa.20170606.04

Md Idris, K. (2002). Gelagat kepatuhan zakat pendapatan gaji di kalangan kakitangan awam Persekutuan, Negeri Kedah. Universiti Utara Malaysia.

Md Razak, M. I., Omar, R., Ismail, M., Amir Hamzah, A. S., \& Hashim, M. A. (2013). Overview of zakat collection in Malaysia: Regional Analysis. American International Journal of Contemporary Research, 3(8), 140-148.

Migin, M. W., Falahat, M., Abd Yajid, M. S., \& Khatibi, A. (2015). Impacts of institutional characteristics on international students' choice of priavte higher education institution in Malaysia. Higher Education Studies, 5(1). http://doi.org/10.5539/hes.v5n1p31

Mohd Noor, A. H., Abdul Rasool, M. S., Md Yusof, R., Ali, S. M., \& Abdul Rahman, R. (2015). Efficiency of Islamic Institutions: Empirical evidence of Zakat Organizations' performance in Malaysia. Journal of Economics, Business and Management, 3(2), 282-286. http://doi.org/10.7763/JOEBM.2015.V3.195

Mohd Noor, M. A., Wahid, H., \& Md Nor, N. G. (2004). Kesedaran membayar zakat pendapatan di kalangan kakitangan profesional Universiti Kebangsaan Malaysia. Islamiyyat, 26(2), 59-67.

Othman, R., \& Abdul Ghani, R. (2011). Sektor ijtimai: Ke arah pemantapan sosio-ekonomi ummah. Journal Pengurusan JAWHAR, 5(1), 99-130.

Pusat Islam UTM. (n.d.). Pengenalan Unit Zakat. Retrieved February 22, 2018, from http://islamiccentre.utm.my/zakat-2/pengenalan-unit-zakat/

Saad, R. A. J. (2010). Gelagat kepatuhan zakat perniagaan di negeri Kedah Darulaman. Universiti Utara Malaysia.

Taha, R., Adam, F., Sultan, U., Abidin, Z., Nurhidayatie, N., Ali, M., \& Ariff, A. M. (2017). Religiosity and Transparency in the Management of Zakat Institutions. Journal of Legal, Ethical and Regulatory Issues, 20(1), 1-9.

Tarimin, M. (2012). Zakat Al-Mal Al-Mustafad: Amalan dan pengalaman di Malaysia. Kuala Lumpur: 
INTERNATIONAL JOURNAL OF ACADEMIC RESEARCH IN BUSINESS AND SOCIAL SCIENCES

Vol. 8, No. 9, Sept. 2018, E-ISSN: 2222-6990 @ 2018 HRMARS

Pusat Pungutan Zakat.

Turner, J., Bartlett, D., Andiappan, M., \& Cabot, L. (2015). Students' perceived stress and perception of barriers to effective study: Impact on academic performance in examinations. British Dental Journal, 219(9), 453-458. http://doi.org/10.1038/sj.bdj.2015.850

Wahab, N. A., Zainol, Z., Abu Bakar, M., Ibrahim, A. Z., \& Minhaj, N. (2016). Developing service quality index for zakat institutions. International Journal of Economics and Financial Issues, 6(7Special Issue), 249-258.

Wahid, H., Abdul Kader, R., \& Ahmad, S. (2012). Penerimaan amil dan asnaf terhadap penyetempatan pengagihan zakat di Malaysia. Jurnal Ekonomi Malaysia, 46(1), 39-51.

Wahid, H., Ahmad, S., \& Abdul Kader, R. (2010). Pengagihan zakat oleh institusi zakat kepada lapan asnaf: Kajian di Malaysia. Jurnal Pengurusan JAWHAR, 4(1), 141-170.

Yusoff, M. B. (2011). Zakat expenditure, school enrollment, and economic growth in Malaysia. International Journal of Business and Social Science, 2(6), 175-181. http://doi.org/10.1017/S1876404511200046

Yusoff, M. B. (2014). Zakat distribution, education, and real income per capita in Malaysia. Review of Strategic and International Studies, VI(3), 43-47.

Zainal, H., Abu Bakar, A., \& Saad, R. A. J. (2016). Reputation, satisfaction of zakat distribution, and service quality as determinant of stakeholder trust in zakat institutions. International Journal of Economics and Financial Issues, 6(7), 72-76. http://doi.org/10.15405/epsbs.2016.08.74 